\title{
Earthquake Response of Model Footings on Soft Clays Strengthened by Stone Columns
}

\author{
Ann M. Raheem*, Mohammed Y. Fattah (D), Makki K. M. Al-Recaby \\ Civil Engineering Department, University of Technology, Baghdad, Iraq. \\ *Corresponding author Email: annmohamed1985@gmail.com
}

\section{H I G H L I G H T S}

- Ordinary and geogrid encased stone columns were used under different conditions.

- Shaking table was manufactured to simulate earthquake loading.

- Dynamic response of stone columns to lateral shaking.

- The values of horizontal displacement increase by increasing the loading frequency.

- The rate of horizontal displacement increases with soil undrained shear strength.

A R T I C L E I N F O

Handling editor: Wasan I. Khalil

\section{Keywords:}

Stone columns

Soft clay

Laboratory models

Horizontal displacement

\begin{abstract}
A B S T R A C T
The objective of the present study is to understand the behavior of soft soil strengthened by stone columns under dynamic seismic load. Ordinary and encased stone columns were used under different conditions. The present study converges around the dynamic response of stone columns of lateral shaking, the interaction of soil frame for understanding settlement mechanisms and the prediction of dynamic load limitations of foundations in soft soils subjected to seismic load (during vibrations). The results of this research will provide the basis for assessing measures to reduce the severity of seismic hazards and the seismic design of foundation structures in soft soils. As a result, soil models will be tested on the shaking table to make seismic ground vibration under several conditions (frequencies, undrianed shear strength of soft soil, for stone columns type both ordinary and encased stone columns). It was concluded that the values of horizontal displacement increase by increasing the loading frequency, as well as the horizontal displacement is faster and greater at $2 \mathrm{~Hz}$ of than 0.5 and $1 \mathrm{~Hz}$ in all cases. The rate of horizontal displacement increases in models on soil of undrianed shear strength $\mathrm{cu}=15 \mathrm{kPa}$ is greater than that in undrianed shear strength $\mathrm{cu}=25 \mathrm{kPa}$ because increasing the strength of the soft soil leads to greater resistance to deformation and a decrease in the level of horizontal displacement.
\end{abstract}

\section{Introduction}

To reduce the problems of soft soils, there are many ways to improve the soil. One of such methods is replacement, sand drains and preloading, lime stabilization, dynamic compaction, and stone or gravel column [1]. Stone columns are considered one of the most important ways to improve weak clay soils as they improve the bearing capacity to bear weak lands and reduce the settlement of the buildings constructed on them in addition to increase the strength of the soil and accelerate the consolidation process and reduce the liquefaction of the soil. It is mainly used for fixing soft soils such as soft clays and silty sand.Stone columns are most often used to improve the behavior of soil with undrianed cohesion cu, in range of 15-25 $\mathrm{kPa}[2]$. Under these values of the strength provided for lateral support, the surrounding soil is insufficient to prevent lateral expansion (bulging) which results in the failure of the columns. Despite of this, the literature suggests that traditional stone columns can be used in soils with a low cu of $6 \mathrm{kPa}$ [3]. The method of using (conventional stone columns) is an effective method for treating soils in terms of time and cost, as (conventional stone columns) have been used to improve soils with solid and flexible structures such as bridges, dams, buildings, and tanks constructed on weak soils[4,5]. Early studies indicated that its stability mostly depended on available lateral support for the soil its surroundings[6,7]. There is another way to improve the very weak clay soils, cu< $15 \mathrm{kPasuch}$ as very soft clay/ silt or peat are the columns covered with a geotextile with high tensile strength [8]. Usually the columns fail to bulge when executed in loose clay soil (cu $<15 \mathrm{kPa}$ ), due to the lack of lateral support provided by the weak soil.To overcome the failure of bulging by encapsulating the granular columns with reinforced industrial materials, geosynthetic encased column which increases the execution of the column through providing lateral 
confinement[9,10]. Many developments had been done by different researchers to improve this technique since that time till now such as:

Qu et al. [11]conducted shaking table model tests to investigate earthquake resistance conduct for stone columns below the seismic intensity of the eighth buildings. The results demonstrated that at acceleration below ( $0.20 \mathrm{~g})$, it is not a liquid foundation compound, the leveling is small and the piles are not stripped; at acceleration $(0.3 \mathrm{~g})$, the land is liquefied out the downhill of the dam and the land inside the (stone column) complex. It is proposed to properly expand the reinforcement scale of the stone foundation. The composite designed stone substrate meets the requirements of earthquake resistance.

Cengiz and Guler[12] evaluated and compared the conventional and geosynthetic wrapped stone columns throughout seismic action placed in clay bed in a massive rectangular tank. To encourage the seismic behavior of columns for embankment. The extent of the seismically developed horizontal strains depends on stiffness of encasement. It is observed that gravel in filled stone columns lowered the settlement more efficiently than sand infill during earthquake. Geotextile wrapped stone columns showed supercilious results compared to conventional stone columns for both under static and seismic loading.

Fahmiet al.[13]investigated the behavior of the soft soil of $15 \mathrm{kPa}$ shear strength and reinforced with (conventional and geogrid reinforced stone columns) subjected to cyclic loading. Also, they used PLAXIS 3D software to check the improved method for using stone columns and field pregnancy exams. The results of the PLAXIS 3D settlement in comparison with the measured settlement in the laboratory yielded a reasonable comparable value of up to $50 \%$ of the design load. Then, recorded settlement shows up to $60 \%$ higher values than finite element analyzes results.

Najim et al. [14]investigated the effect of the shape of footing when resting on clay soil under cyclic loading conditions. Cyclic load testing was carried out on the cohesive soil with three untrained shear strengths (20 kPa, $40 \mathrm{kPa}$ and $70 \mathrm{kPa})$. Two depths were used to combine the foundation (on the surface and $5 \mathrm{~cm}$ ) to observe the effect of foundations depths on sediment change and total vertical stress and two loading rates $(3 \mathrm{~mm} / \mathrm{sec}$ and $6 \mathrm{~mm} / \mathrm{sec})$. The results showed that the transmitted total vertical stress increased with increased loading rate of soft, medium clay.

The objective of the present study is to understand the response of soft soil strengthened with stone columns below dynamic loading earthquake load. Ordinary and encased stone columns were used under different conditions. The current study focuses on the dynamic response of the stone column of lateral shaking, the interaction of soil structure in order to understand the leveling mechanism and prophesy the lateral dynamic of foundations in soft soil below seismic load (during vibrations).

\section{Experimental work}

\subsection{Soil used}

Clayey soil was selected from a position south of Baghdad city in Iraq. The soil has undergone several laboratory experiments to determine its properties. These experiments include: specific gravity according to ASTM D854[15]specifications and Atterberg limits (liquid and plastic limits) according to ASTM D4318[16]. grain size distribution (sieve analysis and hydrometer tests) according ASTM D422[17]specifications. The results showed that the soil consisted of $3 \%$ sand, $75 \%$ clay and $22 \%$ silt. According to the USCS, the soil is classified as CL type. Table 1 shows the chemical and physical properties of the soil.

\subsection{Mashed stone}

The mashed stone was brought from a specific stone factory used to crush large stones. The stone is white in color and angled shapes. According to the guidelines suggested by Al-Sheikhly (2000)[18], the size of the crushed stone was chosen which has a grain around $1 / 7-1 / 9$ diameter of the columns). Particle from 4 to $10 \mathrm{~mm}$ gravity is according to the $04 \mathrm{a}[19]$ to be 2.62 unit weight is 15.5

\begin{tabular}{|c|c|c|}
\hline Properties & Account & \\
\hline Liquid limit $\%$ & 44 & \\
\hline Plastic limit $\%$ & 22 & S1zes ran \\
\hline Plasticity index \% & 22 & determined \\
\hline Specific gravity & 2.7 & $\begin{array}{l}\text { ASTM C128- } \\
\text { and the dry } \\
\mathrm{kN} / \mathrm{m}^{3} \text {. }\end{array}$ \\
\hline
\end{tabular}

Table 1: The physical, chemical 


\section{Production of tests}

\subsection{Production of}

Before

soil layer in the shear strength the clay soil must be
Sand $\%$

Silt $\%$

Clay\%

Maximum dry unit weight

Optimum moisture content

SO3\%

Gypsum content \%

$\mathrm{pH}$

T.D.S.
3

22

75

17.3

17

0.58

1.24

9.02

1.69

\section{model}

soil

preparing the container, the diversity of obtained

against the time after mixing with different liquidity indicators. Consequently, six samples were prepared individually with different liquidity indicators; Each piece isplaced inside a CBR mold in five layers. A special hammer was used for each layer to extract the confined air. After that, the samples were wrapped with polythene paper and left for seven days. With a portable vane shear, the undrained shear strength was measured every day. Such type of tests leaves the soil for a period of rest to recover strength after mixing operationas shown in Figure 1. As the water content increases, the soil shear strength decreases, and the time effect decreases. Figure 2explains the shear resistance variance of the soil with water content for the next 72 hours.

According to the conclusion obtained of Figure 2, the soil is placed in make container of undrained shear strength 15 $\mathrm{kN} / \mathrm{m} 2$ corresponding to water content of $(30 \%)$. Also, the soil was prepared with an undrainedshear strength of $25 \mathrm{kPa}$ corresponding to the water content $(28 \%)$ in the manufactured container. For the soil preparation procedure, $500 \mathrm{~kg}$ of soil was grouped into $20 \mathrm{~kg}$; each group mixed with water to obtain the required consistency. Moist mixed soil is placed in polythene bags for a whole day. Next, five layers of soil have been placed inside a steel container with dimensions $800 \times 800 \times 1000$ mm; each layer is gently hammered using a wooden hammer with dimensions $50 \mathrm{x} 100 \mathrm{~mm}$. The soil has been left for three days to regain its strength between $15 \mathrm{kPa}$ and $25 \mathrm{kPa}$ as suggested by Fattah et al. [20].

\subsection{Composition of the stone columns}

The construction procedure of the stone columns starts directly after the preparation of the bed of soil. The depth of the (stone column) equals $(\mathrm{L} / \mathrm{D}=8)$. The $(\mathrm{PVC})$ tube with a $(50) \mathrm{mm}$ outer diameter was pushed down the soil to a certain depth. Figure 3 shows the process of installing a (stone column). The soil is removed from the inside of the tube with the help of a (hand drill), which was designed for this purpose. Next, the PVC pipe were carefully removed. Thestone is laid in five layers, each layer is stacked by a $(44 \mathrm{~mm})$ diameter rod to obtain a density for $15.5(\mathrm{kN} / \mathrm{m} 3)$.

\subsection{Composition of the (encased stone column)}

Geogrid pipes are made by deforming and stitching the geogrid mesh roll with nylon threads along the coated stone column length L / D = 8 and diameter (48) $\mathrm{mm}$. Then the construction procedures for the encased stone column began after the soil floor was prepared. A sacred plastic tube for a $50 \mathrm{~mm}$ outer diameter. The plastic tube is pushed into the soil. Manual auger is used to remove the soil inside the plastic tubes. It is then placed inside a tube geogrid stone column holeusing a PVC tube. The stone is laid of layers each layer is stacked by rod to obtain a density for $15.5\left(\mathrm{kN} / \mathrm{m}^{3}\right)$.

Figure 4 shows the process building the (encased stone column).

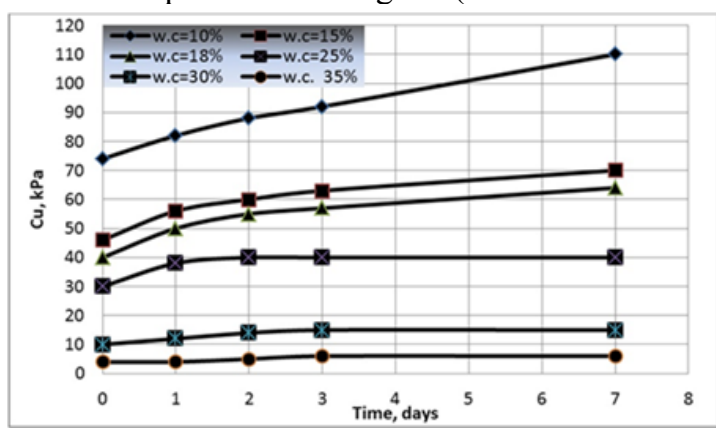

Figure 1: Relationship of the undrained shear strength for time.

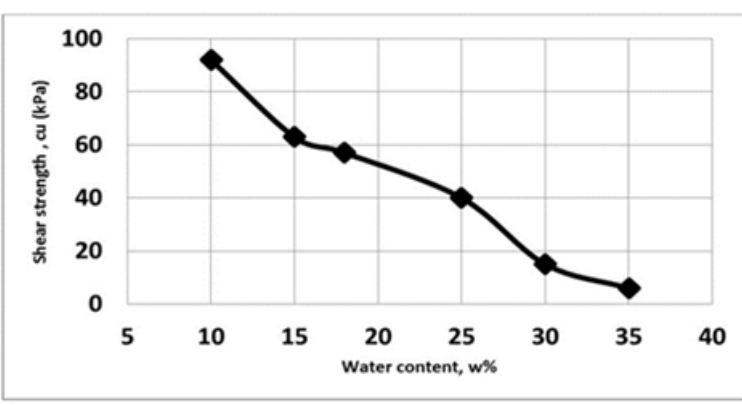

Figure 2: Figure 1: Variation of the undrained shear strength with watercontent after 3- day curing. 


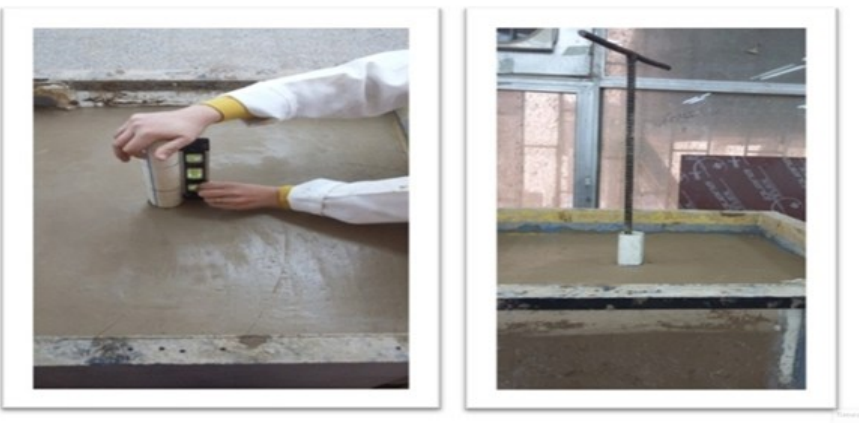

Figure 3: The process of stone column installation

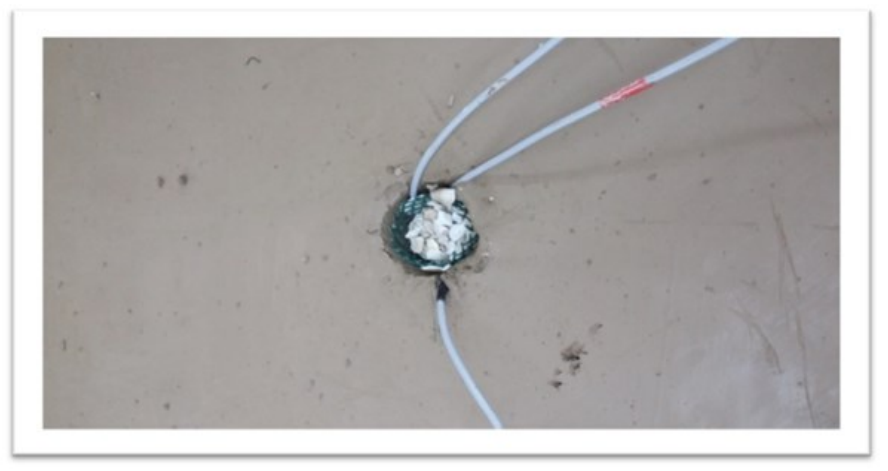

Figure 4: Steps of geogrid stone column installation.

\section{Model design and manufacturing (Shaking table model)}

To simulate the earthquake excitation and loading in laboratory, there are several techniques that can be followed, one of them is using a shaking table. The shaking table is essential laboratory equipment which simulates the loading occurring during dynamic excitation as in earthquake. The loading type can be harmonic, random, real earthquake motion, etc. The shaking table is one of the easiest inexpensive techniques, it can be connected to any software and PC programs, and can simulate any type of dynamic loading.

In the present study, the input motion that's was generated by the shaking table is dynamic motion of harmonic shape with different frequencies.

The shaking table device consists mainly of four parts as shown in Figure 5:

- Shaking table base.

- Electrical motor and Ac-drive.

- Steel box.

- Damping system.

\section{Steps Model Test}

Typical tests were performed on improved natural soil using stone column. The foundation has been laid with dimensions (75 x 75) mm2at surface from soft soil model and (conventional and encased column) model. The horizontal displacement of the foundation has been measured using time-off-light sensor(LVDT) under earthquake loading (during shakings). Flight sensor technology to measure the time taken by pulses emitted by infrared laser light to precisely reach the nearest object and be reflected back to the detector, so that it can be considered a small lidar based system as shown in Figure 6 .

\section{Consequence and Debate}

Figure 7 indicates that an untreated soil faces a greater horizontal displacement than the stone-reinforced soil model. In addition, the soil supported of (conventional stone column) has more horizontal displacement than for soil supported of (geogrid stone column) at frequency $0.5 \mathrm{~Hz}$ andundrained shear strength $\mathrm{cu}$ of $15 \mathrm{kPa}$.

Figure 8 presents the results of horizontal displacement -time relationship of model footing on soft clay under $1 \mathrm{~Hz}$ frequency andundrained shear strength cu of $15 \mathrm{kPa}$. The untreated soil model showed more horizontal displacement than the stone column supported soil models. Moreover, the reinforced soil of (stone column) model flop faster than soil reinforced by (geogrid stone column).

Figure 9 shows the results of the dynamic load test at a frequency $2 \mathrm{~Hz}$ and an undrained shear strength of $15 \mathrm{kPa}$. The soil alone model flop quicker for stone-supported clay models. In addition, it is observed that the model of the reinforced soil with a stone column is a horizontal displacement more than of the soil supported for a (stone column) covered with geogrid materials. This can be described for model footing on soft clay under $2 \mathrm{~Hz}$ frequency and $\mathrm{cu}=15 \mathrm{kPa}$ will reach failure at shorter time and the value of the horizontal displacement will be more than the models at the $1 \mathrm{~Hz}$ frequency. The model 
footing on soft clay under $1 \mathrm{~Hz}$ frequency and $\mathrm{cu}=15 \mathrm{kPa}$ failure will arrive faster and will have horizontal displacement values more than models below $0.5 \mathrm{~Hz}$ frequency.

Figure 10 presents the results of horizontal displacement -time relationship of model footing on soft clay under $0.5 \mathrm{~Hz}$ frequency and undrained shear strength cu of $25 \mathrm{kPa}$. The untreated soil model revealed a greater horizontal displacement than the stone-supported soil models. Moreover, the stone-reinforced soil model will fail in a shorter time than the stone-reinforced soil model covered with geogrid. Figure 11 shows that soil failure is not supported faster than the stone-supported soil model. In addition, the soil model supported by (conventional stone column) flop more than soil supported by a stone column covered with geogrid materials under frequency $1 \mathrm{~Hz}$ and an undrained shear strength cu of $25 \mathrm{kPa}$.

Figure 12 shows the consequence of dynamic load test at a frequency $2 \mathrm{~Hz}$ and undrained shear strength of $25 \mathrm{kPa}$. It appears that the untreated soil pattern fails faster than the stone column supported soil models. Furthermore, the stone column reinforced soil model will fail more than the stone-reinforced soil model coated with geogrid. It can also be described that the model footing on soft clay under $2 \mathrm{~Hz}$ frequency and cu $=25 \mathrm{kPa}$ will fail faster. The value of horizontal displacement is more than the model at the frequency of $1 \mathrm{~Hz}$. The model footing on soft clay below the frequency of $1 \mathrm{~Hz}$ and cu=25 $\mathrm{kPa}$ will fail quicker and the rate for horizontal displacement more than models at the frequency $0.5 \mathrm{~Hz}$. Table 2 summarizes the values of maximum horizontal displacement during shaking of footing models.

Table 2 summarizes the values of maximum horizontal displacement during shaking of footing models. With reference to Table 2, it can be observed that when increasing the frequency, the horizontal displacement increases. In the case of soft clay (15) $\mathrm{kPa}$ when increasing the frequency from (0.5-1), the horizontal displacement increases by (16.7- 46.2)\% from soil untreated to soil reinforced with ordinary stone column. Also the horizontal displacement increases at a rate of $(16.7-30.0) \%$ when increasing the frequency from $(0.5-2) \mathrm{Hz}$. With reference to the above figures and table 2 , it is shown that the horizontal displacement values of the model footing on clay having undrianed shear strength of $25 \mathrm{kPa}$ is less than that of model footing resting on clay with undrianed shear strength of $15 \mathrm{kPain}$ all cases, whether the soil is untreated or treated. For example, the horizontal displacement will decrease at a rate of $(46.2-37.5) \%$ if the model is transferred from model on untreated soil to the model on ordinary stone columns and at the frequency $1 \mathrm{~Hz}$. At frequency $2 \mathrm{~Hz}$, the value of the horizontal displacement decreases from (30-16.7)\% when the shear resistance increases from (15-25)\% to the clay soil when the model is transformed from model on untreated soil to a model footing on soil treated with ordinary stone columns.

In the case of soil treatmed with geogrid encased stone columns, the horizontal displacement will decrease at a rate of $(61.5-50) \%$ from the untreated soil when increasing the undrianed shear strength of the clay soil from $(15-25) \mathrm{kPa}$ at the frequency $1 \mathrm{~Hz}$. And it also decreases at a rate $(50-33.3) \%$ when increasing the undrianed shear strength of the clay soil from $(15-25) \mathrm{kPa}$ at the frequency $2 \mathrm{~Hz}$.As well as referring to the above figures and the table 2 , it is noted that there is a decrease in the horizontal displacement values for model footing on untreated clay soils compared to the model footing on clay soils treated with ordinary stone column and thus the values of horizontal displacement are less for the model footing on clay soils in the stone column encased than the model footing of the clay soil treated with the ordinary stone column.For example, the values of horizontal displacement decrease by about (16.7) \% from the model footing on untreated clay soils from the model footing of clay soils treated with the ordinary stone column at frequency $0.5 \mathrm{~Hz}$ and undrianed shear strength $15 \mathrm{kPa}$. In addition, the values of horizontal displacement decrease by about (20) \% from the model footing on clay soils treated with ordinary stone column from the model footing of clay soils treated with geogrid encased stone column at frequency $0.5 \mathrm{~Hz}$ and undrianed shear strength $15 \mathrm{kPa}$.

At frequency $2 \mathrm{~Hz}$ and undrianed shear strength $15 \mathrm{kPa}$, the values of horizontal displacement decrease by about (30) \% from the model footing on untreated clay soils for the model footing of clay soils treated with ordinary stone column, and the values decrease by about (28.6) \% for the same model footing on soil treated with ordinary stone column from the model footing of clay soils treated with the geogrid stone column.

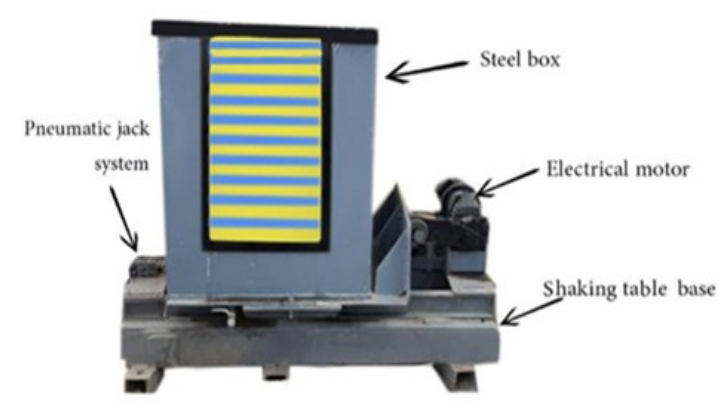

Figure 5: Figure 1: Shaking table setup (Fattah et al.2016) [21].

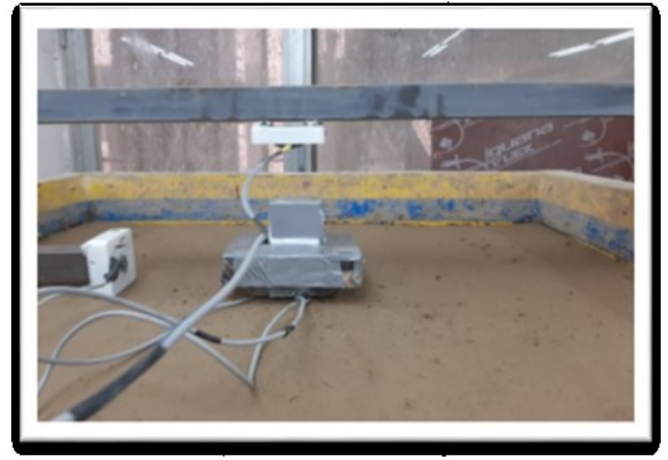

Figure 6: Figure 1: Model testing procedure. 


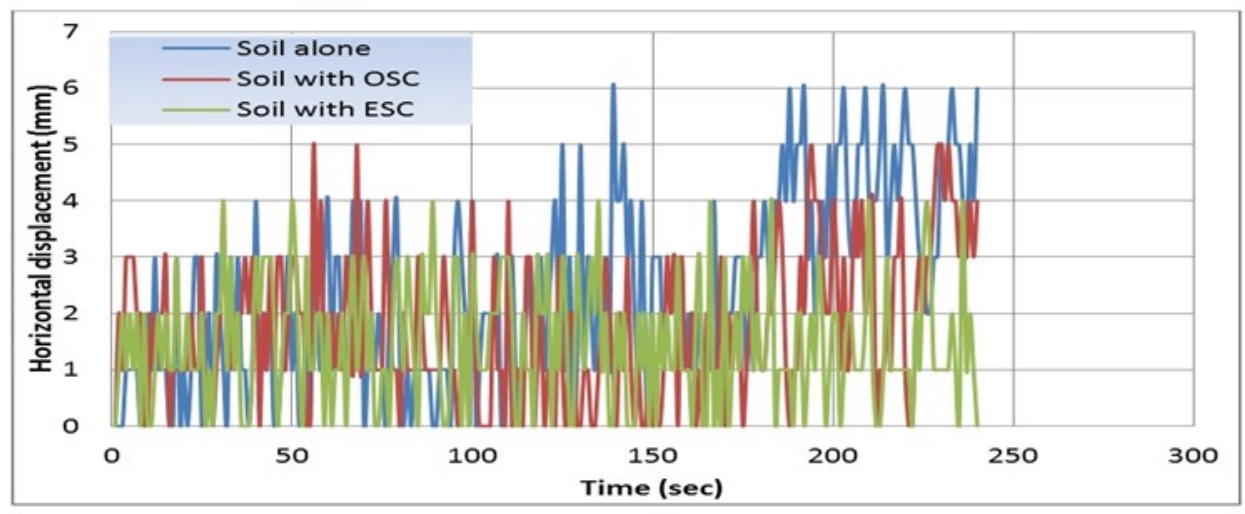

Figure 7: Produce horizontal displacement of untreated soils, supported soils for (stone column) under $0.5 \mathrm{~Hz}$ and $\mathrm{cu}=15 \mathrm{kPa}$.

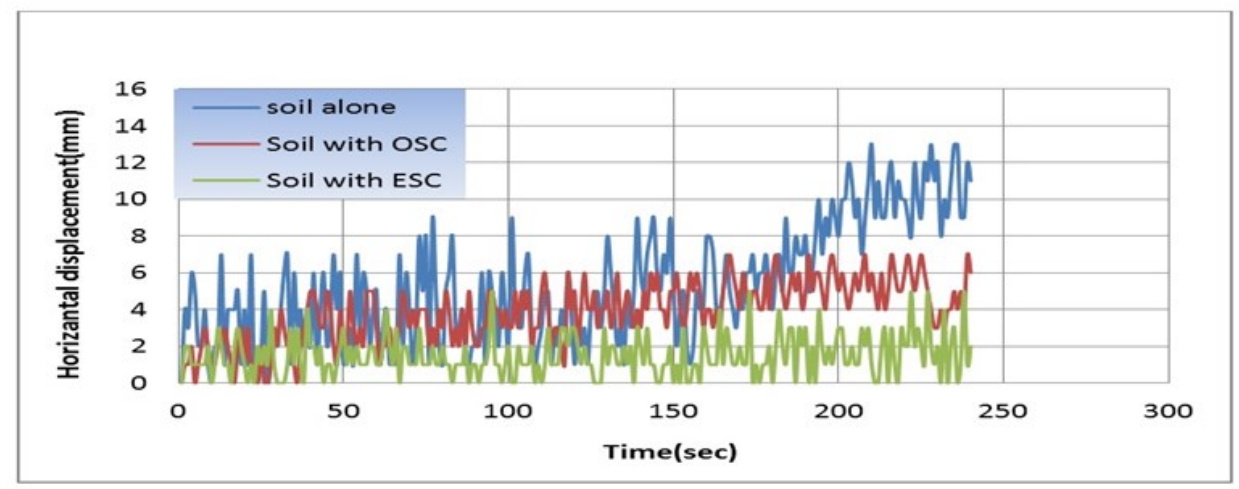

Figure 8: Produce horizontal displacement of untreated soils, supported soils for (stone column) under $1 \mathrm{~Hz}$ and $\mathrm{cu}=15 \mathrm{kPa}$.

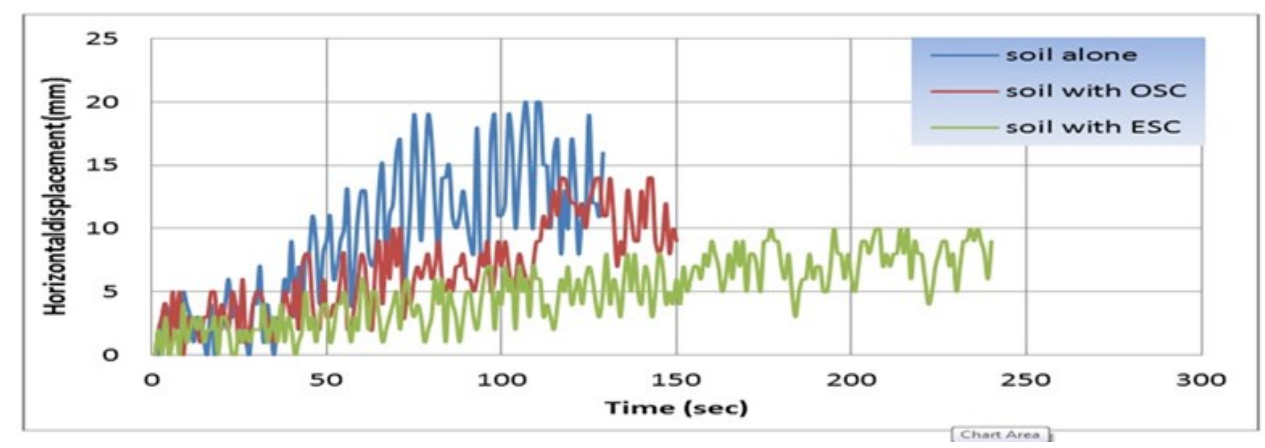

Figure 9: Produce horizontal displacement of untreated soils, supported soils for (stone column) under $2 \mathrm{~Hz}$ and $\mathrm{cu}=15 \mathrm{kPa}$.

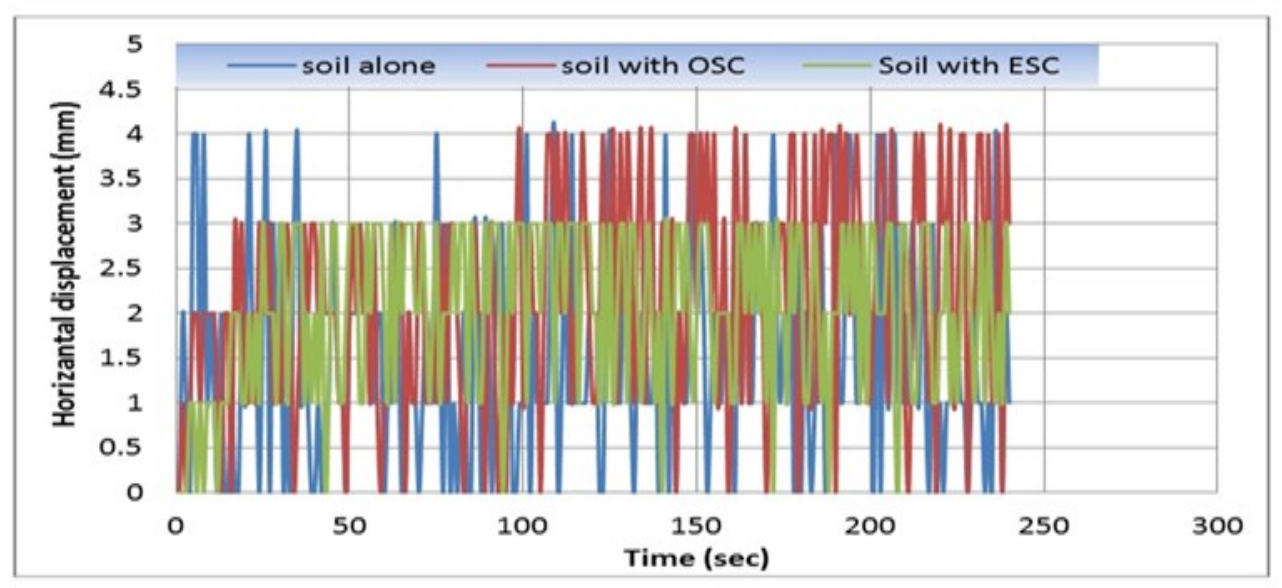

Figure 10: Produce horizontal displacement of untreated soils, supported soils for (stone column) under $0.5 \mathrm{~Hz}$ and $\mathrm{cu}=25 \mathrm{kPa}$. 


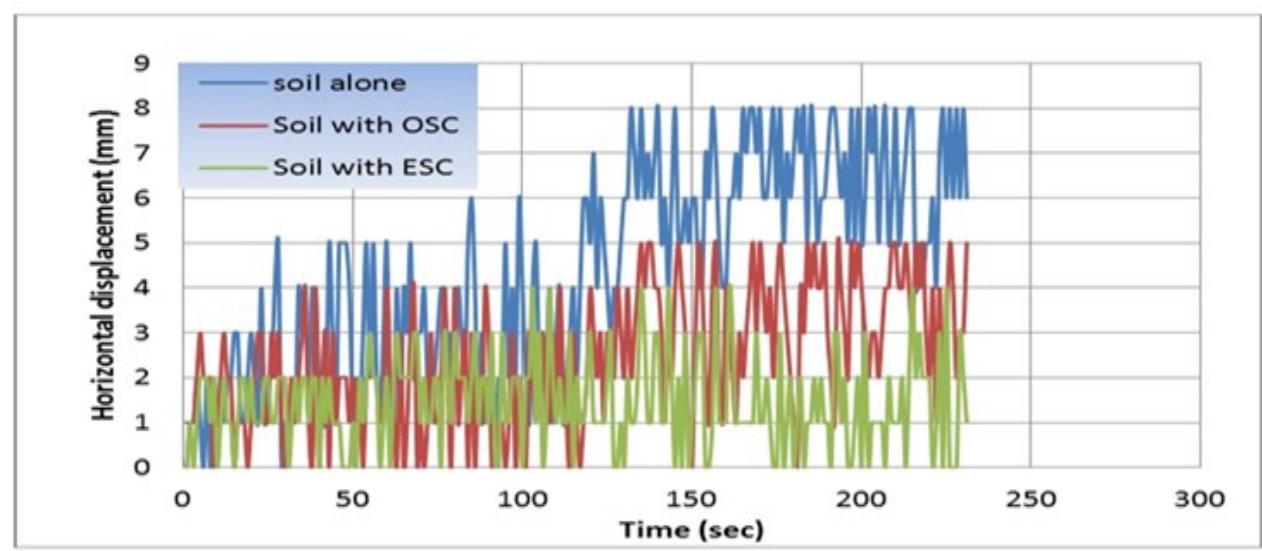

Figure 11: Produce horizontal displacement of untreated soils, supported soils for (stone column) under $1 \mathrm{~Hz}$ and $\mathrm{cu}=25 \mathrm{kP}$

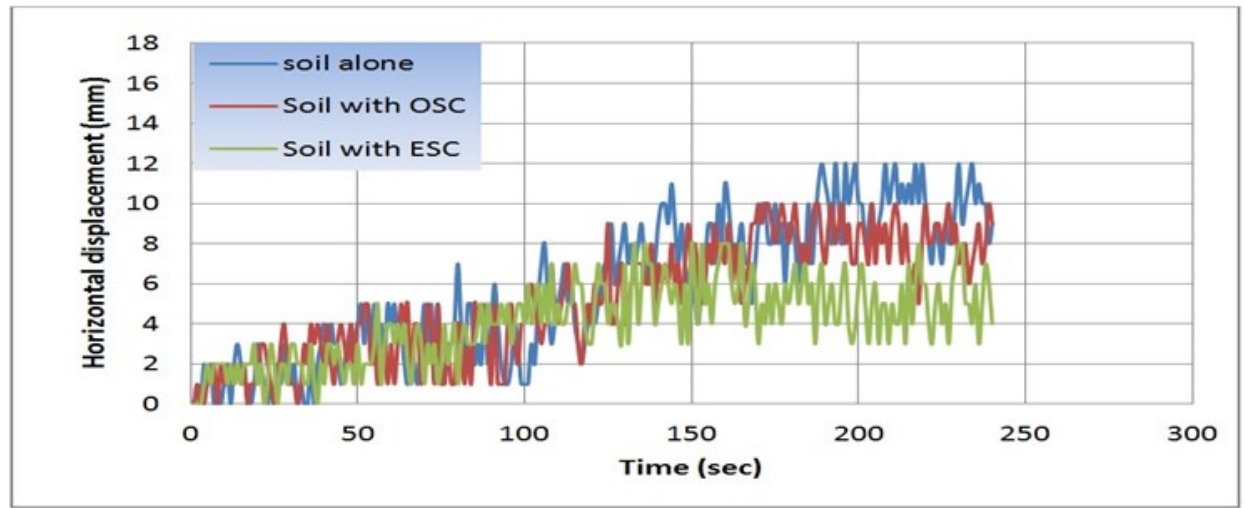

Figure 12: Produce horizontal displacement of untreated soils, supported soils for (stone column) under $2 \mathrm{~Hz}$ and $\mathrm{cu}=25 \mathrm{kPa}$.

Table 2: Maximum horizontal displacement of the model footing resting on soft clay and on ordinary and encased stone columns under different frequencies and undrianed shear strengths of soft clay.

\begin{tabular}{|c|c|c|c|c|c|c|c|c|c|}
\hline \multirow{4}{*}{$\begin{array}{l}\text { Undrianed shear } \\
\text { strength, cu (kPa) }\end{array}$} & \multicolumn{9}{|c|}{ Max horizontaldisplacement(mm) } \\
\hline & \multicolumn{3}{|c|}{ Untreated soil } & $\begin{array}{r}\text { Treated } \\
\text { sto } \\
\end{array}$ & $\begin{array}{r}S \\
\text { vith } \\
\text { col } \\
\end{array}$ & $\begin{array}{l}\text { l type } \\
\text { rdinary } \\
\text { mn }\end{array}$ & \multicolumn{3}{|c|}{$\begin{array}{l}\text { Treated with geogrid } \\
\text { encased stone column }\end{array}$} \\
\hline & \multicolumn{6}{|c|}{ Frequency $(\mathrm{Hz})$} & & & \\
\hline & 0.5 & 1 & 2 & 0.5 & 1 & 2 & 0.5 & 1 & 2 \\
\hline 15 & 6 & 13 & 20 & 5 & 7 & 14 & 4 & 5 & 10 \\
\hline 25 & 4 & 8 & 12 & 4 & 5 & 10 & 3 & 4 & 8 \\
\hline
\end{tabular}

\section{Conclusion}

1) The values of horizontal displacement increase by increasing the loading frequency, as well as the horizontal displacement is faster and greater at $2 \mathrm{~Hz}$ of than 0.5 and $1 \mathrm{~Hz}$ in all cases.

2) The rate of horizontal displacement increases in models on soil of undrianed shear strength $\mathrm{cu}=15 \mathrm{kPa}$ is greater than that in undrianed shear strength $\mathrm{cu}=25 \mathrm{kPa}$. This is due to the increased strength of the soft clay and leads to greater resistance to deformation and consequently to the down level of horizontal displacement

Author Contribution

All authors contributed equally to this work.

\section{Funding}

This research received no specific grant from any funding agency in the public, commercial, or not-for-profit sectors.

\section{Data Availability Statement}

The data that support the findings of this study are available on request from the corresponding author.

\section{Conflicts of Interest}


The authors declare that there is no conflict of interest.

\section{References}

[1] H. G.Kempfert, , and B.Gebreselassie, "Excavations and foundations in soft soils," Springer Science and Business Media, (2006).

[2] D. A.Greenwood, "Load tests on stone columns In Deep foundation improvements: Design, construction, and testing," ASTM International, (1991).

[3] R. D.Barksdale, andR. C.Bachus, "Design and construction of stone columns," US Department of Transportation, Federal Highway Administration, (1983).

[4] A.Salahi, H.Niroumand, and K.Kassim, "Evaluation of stone columns versus liquefaction phenomenon," Scientific World Journal, 20th ed, 2015,pp.739-759

[5] M. Y.Fattah,B. S.Zabar, andH. A. Hassan, "Experimental analysis of embankment on ordinary and encased stone columns," International Journal of Geomechanics,Vol. 16, No. 4, pp.04015102, 2016.

[6] M. K.Malik, and I. R. Karim, "Slope Stability Analysis of Haditha Dam after Earthquake using Geo-Studio Software," Engineering and Technology Journal,Vol. 39,No.4A,pp. 599-613, 2021.

[7] H. H.Karim, Z. W. Samueel, andD. A. A. Hussein, "Correlation of Soil Liquefaction Potential Index and Geotechnical Properties for Baghdad City, Iraq," Engineering and Technology Journal, Vol.38, No.6A, pp. 813-824, 2020.

[8] M. Y.Fattah, and Q. G. Majeed, "Finite element analysis of Geogrid encased stone columns," Geotechnical and Geological Engineering, Vol. 30, No.4, pp.713-726, (2012).

[9] D.Alexiew, D.Brokemper, and S.Lothspeich, "Geotextile encased columns (GEC): load capacity, geotextile selection and pre-design graphs," In Contemporary Issues in Foundation Engineering, pp. 1-14, 2005.

[10] M.Raithel, andH. G.Kempfert, "Calculation models for dam foundations with geotextile coated sand columns," In ISRM International Symposium, International Society for Rock Mechanics and Rock

Engineering,2000.

[11] M.Qu, Q.Xie, X.Cao, W.Zhao, J.He, and J.Jin, "Model test of stone columns as liquefaction countermeasure in sandy soils," Frontiers of Structural and Civil Engineering, Vol.10,No.4,pp. 481-487,2016.

[12] C.Cengiz, and K. S Fahmi, "Seismic behavior of geosynthetic encased columns and ordinary stone columns," Geotextiles and Geomembranes, Vol.46,No.1, pp.40-51,2018.

[13] K. S.Fahmi, M.Fattah, and A.Shestakova, "Behavior of foundation soil improved by stone column under cyclic load," In MATEC Web of Conferences, Vol. 239, pp. 05015,2018.

[14] A. N.Najim, M. Y.Fattah, and M. K. Al-Recaby, "Cyclic Settlement of Footings of Different Shapes Resting on Clayey Soil," Engineering and Technology Journal, Vol.38,No.3A, pp.465-477, 2020.

[15] ASTM, D854, "Standard Test Method for Specific Gravity of Soil Solids by Water Pycnometer", Soil and Rock (I), Vol. 04.08, 2003.

[16] ASTM, D4318, "Standard Test Method for Liquid Limit, Plastic Limit, and Plasticity Index of Soils", Soil and Rock (I), Vol. 04.08,2003.

[17] ASTM, D422, "Standard Test Method for Particle-Size Analysis of Soils", Soil and Rock (I),Vol. 04.08.18,2003.

[18] A.A.Al-Shaikhly, "Effect of Stone Grain Size on the Behavior of Stone Column", M.Sc. Thesis, Building and Construction Engineering Department, University of Technology, Iraq, 2000.

[19] ASTM C128-04a Standard Test Method for Density, Relative Density (Specific Gravity), and absorption of Fine Aggregate, USA.

[20] M. Y.Fattah,K.T.Shlash and M.J.Al-Waily"Stress concentration ratio of model stone columns in soft clays," Geotechnical Testing Journal, ASTM,Vol.34,No.1, pp. 61-71, 2011.

[21] M. Y.Fattah, H. H.Karim, and M. K. M.Al-Recaby, "Dynamic behavior of pile group model in two-Layer sandy soil subjected to lateral earthquake excitation," Global Journal of Engineering Science and Research Management, Vol.3, No.8, pp. 57-80, 2016. 